\title{
The theoretical separation of brand equity and brand value: Managerial implications for strategic planning
}

Received (in revised form): 19th December, 2006

\section{RANDLE D. RAGGIO}

is Assistant Professor of Marketing at the E.J. Ourso College of Business at Louisiana State University, where he teaches the capstone marketing strategy course for senior-level marketing majors. He has taught courses at the undergraduate and MBA levels, as well as executive education. His research is focused on branding, brand equity and strategic issues in B2B services markets. Prior to entering academia, he was the marketing director for Kidpower, the toy company that marketed products such as the Funnoodle (the long, colourful foam swimming pool 'noodles'). He produced more than 13 commercials that aired on US national cable television and appeared on QVC three times. In 1998, he was appointed to the Toy Manufacturers of America Blue Ribbon Communications Panel.

\section{ROBERT P. LEONE}

is Berry Chair of New Technologies in Marketing Professor of Marketing, Fisher College of Business, The Ohio State University. He has published extensively in top marketing journals and is frequently quoted in publications such as Business Week and The Wall Street Journal. He received the Maynard Award from the American Marketing Association for a paper published in Journal of Marketing judged to contribute most to theory in marketing. He has served on the editorial boards of Journal of Marketing, Marketing Science and Journal of Advertising. His teaching interests lie in the area of marketing management and strategy, marketing research and forecasting. He has taught courses at the undergraduate, MBA and PhD levels, as well as various modules in executive education programmes. He is a three-time recipient of the James L. Ginter MBA Marketing Elective Teaching Award at Ohio State (most recently in 2006). Among other honours, he also won the Fisher College Graduate Teaching Award in 1996.

\section{Keywords}

brand equity; brand value; customer equity; marketing strategy
Randle D. Raggio

E.J. Ourso College of Business, Louisiana State University,

3 I 22 C CEBA Building,

Baton Rouge, LA 70703, USA

Tel: + I (225) 578-2434

Fax: + I (225) 578-86I6

E-mail: raggio@Isu.edu

\section{Abstract}

During the past 15 years, brand equity has been a priority topic for both practitioners and academics. In this paper, the authors propose a new framework for conceptualising brand equity that distinguishes between brand equity, conceived of as an intrapersonal construct that moderates the impact of marketing activities, and brand value, which is the sale or replacement value of a brand. Such a distinction is important because, from a managerial perspective, the ultimate goal of brand management and brand equity research should be to understand how to leverage equity to create value.

Journal of Brand Management (2007) 14, 380-395. doi:10.1057/palgrave.bm.2550078; published online 2 March 2007

\section{BRAND EQUITY VERSUS BRAND VALUE}

In this paper, we present a new conceptual model that establishes brand equity and brand value as two distinct constructs. Brand equity moderates the impact of marketing activities on consumers' actions, implies a consumer-based focus, and represents one of many factors that contribute to brand value, which we define as the sale or replacement value of a brand, and which implies a companybased perspective. We believe that one of the primary reasons no generally accepted measure of brand equity has surfaced in the past 15 years is that brand equity and brand value frequently are treated as the same construct. ${ }^{1-4}$ We suggest that the first 
step required to understand 'true' brand equity is to develop a conceptual framework that clearly separates the concepts of brand equity and brand value. In making this distinction, we argue that most of the outcome measures used in previous brand equity research have focused more on brand value than on brand equity.

We subsequently provide more precise definitions, but for conceptual purposes at this point, we suggest that brand equity represents what the brand means to the consumer, whereas brand value represents what the brand means to a focal company. ${ }^{5}$ Therefore, each represents not only a distinct construct but a unique perspective as well. Separating the two constructs opens a discussion about the ways that brand equity contributes to brand value $e^{6,7}$ and how both can be increased, which should be the focus of both researchers and practitioners.

We note that our focus is on customeror consumer-based brand equity throughout the paper, but the concepts could easily be extended to consider other constituencies (eg suppliers, partners, distribution, etc).

In their award-winning paper, Ailawadi et al. ${ }^{8}$ basically argue that brand equity is when more people line up to pay more for a branded versus non- or otherbranded offering. We allow that this is one potential outcome of brand equity, but this outcome is not necessary to establish brand equity's existence, since it presupposes and requires competition, as well as purchase. We suggest that it is possible for a pioneering brand that has established a new category to build brand equity during the time when competitors do not yet exist. Consider Apple's iPod. Introduced in October 2001, we suggest that its continued leadership more than five years after introduction is due to the positive equity built during the time before it faced competition. Likewise, it should also be possible for a brand that has a legal monopoly and faces no competition, to build brand equity, just as it should be possible for a store brand or 'value' brand to build equity without the manifestation of large sales numbers or price premiums.

Consider the Rolex brand. A small sample of $\mathrm{PhD}$ students at a large Midwestern US university all agreed that Rolex has brand equity. But when asked who has or would purchase a Rolex watch, not one of the students said they own or plan to purchase a Rolex. The fact that a person decides to not purchase a brand is not proof that brand equity does not exist. In the same fashion, the fact that a person does purchase a brand-even at a price premium-cannot be conclusive proof that brand equity does exist. Purchase may indicate only that the brand is just objectively good ${ }^{9}$ and that a nonlinear relationship exists between the amount of 'goodness' that the brand possesses (over competitors) and price. Therefore, while large market share or price premium may be outcomes of brand equity, these outcomes by themselves, are neither necessary nor sufficient to establish equity.

As Keller ${ }^{10}$ asserts, 'Any potential encounter with a brand-marketing initiated or not-has the opportunity to change the mental representation of the brand and the kinds of information that can appear in consumer memory'. Such an encounter may occur when a consumer views only the name, logo or packaging of the brand and automatically generates perceptions about and/or associations with the brand. These perceptions and/or associations contribute to brand equity. Thus, we suggest it is not possible for a brand to have no brand equity. Because it is hard to imagine a brand void of any associations, 
some level of brand equity, even if small, must always exist; however, this equity is established by the existence of associations in memory, not by outcomes such as purchase.

The distinction between equity and value becomes clear if we imagine two firms bidding to purchase a brand from a third firm. At a particular point in time, assuming an objective measure of brand equity exists and is used by all three firms, each firm should be looking at the same 'number' for the brand's equity. The different prospective owners might, however, develop totally different brand valuations on the basis of their existing capabilities and resources, which would impact their ability to leverage that brand equity to generate value. Likewise, the value of the brand to a particular bidder may increase (decrease) if the new owner is (not) able to leverage existing brand equity. Different bid prices do not represent different assessments of brand equity calculated by the firms but rather different valuations based on their perceived abilities to leverage existing and build new brand equity. Moreover, if a purchase takes place, the purchaser's valuation must have been higher than that of the current owner, ${ }^{11}$ again suggesting the idiosyncratic nature of brand value. It should follow that because the prospective owner determines a valuation for a brand prior to purchase, brand equity does not immediately increase for consumers when ownership is transferred. Brand equity may increase when consumers become aware of the new ownership, but only if consumers hold positive associations for the new owner and these positive associations contribute to increased equity.

Figure 1 presents a simplified version of the process a firm might follow to value a brand. Basically, the valuation process is approached from the perspective of the firm and involves 'following the money' as it flows from the marketplace into the firm and then tracking how this activity impacts shareholder value. Starting with marketplace activity, individual-level outcomes (eg purchases) are aggregated up to a brand level and these brand-level outcomes directly impact the value of the brand. Ultimately, the value of the brand impacts shareholder value. This is a reasonable process for valuation, but in much of the marketing literature, the first two boxes (individual- and brand-level outcomes) have become accepted as measures of brand equity. We believe this is inappropriate and may produce an inaccurate measure of true brand equity. As

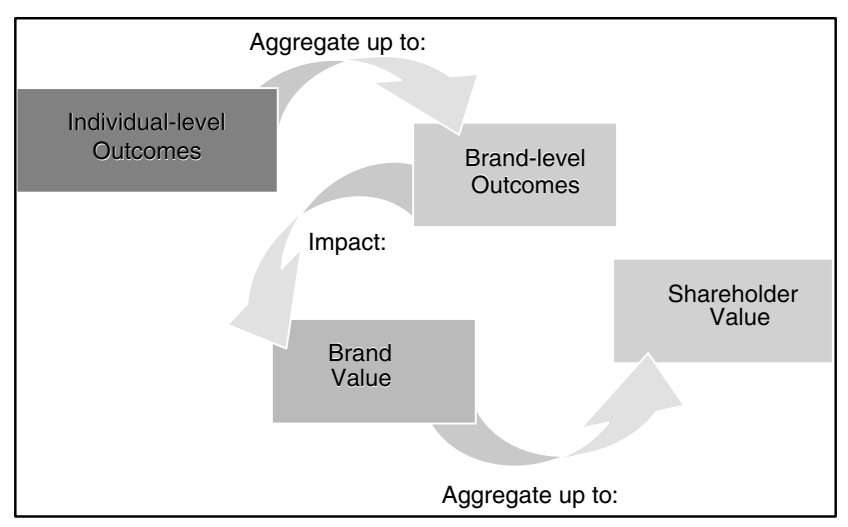

Figure I Simplified brand valuation process 


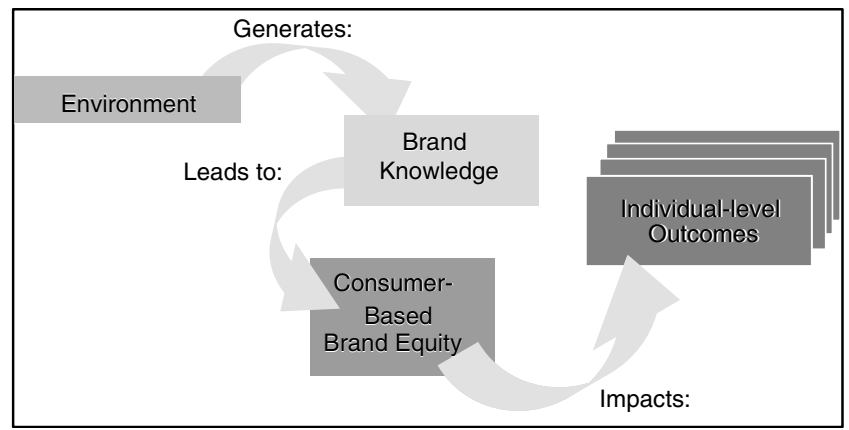

Figure 2 Moving upstream to the drivers of individual-level outcomes

demonstrated above, brand equity may account for the presence of some of these outcomes, but focusing on outcomes confounds objective goodness of products with equity, and does not account for equity that may exist among those who are not prospects for a brand.

What Figure 1 lacks is an explanation for where the individual-level outcomes come from. To understand the source of these outcomes, it is necessary to take the consumer's perspective. Figure 2 shows how the environment, with all its information (marketing-related and not) contributes to brand knowledge, which Keller $^{12}$ links with brand equity. Consumerbased brand equity then impacts the individual-level outcomes that are observable in the marketplace. Even if we have multiple observations for a single individual, it is still critical to control for alternative explanations (eg objectively good products) before concluding that marketplace actions are caused by brand equity, and we must be careful to not assume that measures of brand equity based on individual-level outcomes fully capture all of a brand's brand equity.

A specific case that demonstrates the distinction between equity and value is the $\$ 1.7 \mathrm{bn}$ purchase of Snapple by Quaker Oats in 1994. Quaker Oats' distribution strength rested in supermarkets and drug stores, not the smaller convenience stores and gas stations that constituted more than half of Snapple's sales at the time of purchase. ${ }^{13}$ Because Quaker Oats was unable to increase supermarket and drug store sales enough to compensate for lost convenience and gas station sales, Quaker was forced to sell Snapple for a mere $\$ 300 \mathrm{~m}$ only three years later. In this case, Snapple's brand value decreased enormously over the three years that Quaker Oats owned it, but this decrease may have had nothing to do with its brand equity, which could have stayed the same over this time period or even increased due to its new exposure in supermarkets and drug stores. In other words, neither a brand's purchase price nor a dramatic change in its selling price provide information about the magnitude or movement of a brand's equity.

Not only are the constructs of brand value and brand equity different, they are not necessarily directionally related. Consider the decision by Lee Jeans to increase its distribution by agreeing to sell its product at Wal-Mart. Ceteris paribus, Lee should have been able to generate higher revenues due to its huge distribution gains, and consequently, the value of the Lee brand may have increased. It does not follow, however, that the brand equity for Lee Jeans would increase. The impact on 
Lee's image of selling its jeans at a store like Wal-Mart may result in decreased brand equity within one or more segments of Lee's consumers. So though Lee's brand value was increasing because it was sold at Wal-Mart, its brand equity may have decreased within many consumers. As these cases show, brand equity and brand value are not different dimensions of the same construct-they are different constructs.

From the preceding discussion and as shown in Figures 1 and 2, we believe it should be clear that brand equity is not the same thing as the outcomes that it influences, and should certainly not be confused with brand value. Each construct is distinct and suggests a different perspective (ie consumer versus company). Most critically for practitioners and market research firms, because brand equity and brand value are two related but separate constructs, it is impossible to produce a single number that reliably captures simultaneous changes in consumer perceptions of the brand and the market value of the brand, as they may move in concert, one may lag the other, or they may even move in opposite directions.

In the sections that follow, we discuss how brand equity contributes to brand value $^{14}$ and demonstrate that brand value may be driven by elements beyond brand equity that are not even directly related to customers or consumers in general.

\section{Brand equity}

Among research in the brand equity area, a single, uniformly accepted theoretical foundation still has not emerged. Such a theoretical foundation should describe how to develop brand equity and leverage it to create value by clarifying the distinc- tion between brand equity and brand value in an appropriate framework.

In the previous section, we suggested that brand value is specific to a particular owner and implies a unique, companybased perspective. We now propose that brand equity resides within, and is specific to, each consumer. ${ }^{15-17}$ Therefore, a single, individual-level, objective measure of 'true' brand equity exists because brand equity resides within consumers, not within the brand. ${ }^{18,19}$

\section{Brand equity defined}

Consistent with prior authors ${ }^{20,21}$ we suggest that a brand represents a promise of benefits to a customer or consumer (business or individual). Brand managers may choose to focus brand-building activities (eg advertising) on one or more of the functional, emotional, social, safety, etc benefits of the brand, but ultimately, consumers decide not only their perceptions of the degree to which the promise of brand manager-defined benefits is met, but also whether other benefits are also available from the brand. For example, Kevin Roberts, CEO of Saatchi \& Saatchi was in a music studio when the singer Neil Young walked in wearing a T-shirt with the Tide laundry detergent's bull'seye logo, implying (according to Roberts) 'coolness', a benefit not explicitly emphasised by the brand managers at Procter \& Gamble, Tide's manufacturer. ${ }^{22}$ It is clear that consumers may derive unintended emotional, safety, prestige, or other benefits from brands, and that these benefits can be important to consumers.

Whereas it has long been accepted that all goods and services provide benefits, ${ }^{23,24}$ it should follow that consumer perceptions determine whether a brand's promise is salient and whether or not the brand has met its promise. Furthermore, these 
perceptions are imperfectly measured simply by observing outcome measures based on purchase behaviour.

We therefore define brand equity as the perception or desire that a brand will meet a promise of benefits. We include 'desire' as a component of brand equity for the situations where consumers are pulling for a brand and want it to succeed, as would be the case for nostalgia brands, or sports brands (eg football teams). Rossiter and Percy $^{25}$ state that "all ads make a "promise" and thereby invoke hope...'. We suggest that since it, too, represents a promise, a brand invokes hope and desire on the part of consumers. The combination of belief based on evidence and hope are the foundations of brand equity.

Operationally, we conceptualise brand equity as a moderator of the impact of marketing activities (products, advertising messages, etc) on consumers' actions (consideration, purchase, etc). As a moderator, it is clear that brand equity contributes to particular outcomes, but cannot be identical to the outcomes themselves. Brand equity makes marketing activities more or less effective than they would be if equity did not exist. As Smith and Park ${ }^{26}$ and Srivastava and Shocker ${ }^{27}$ show, strong brands contribute to reduced marketing costs, supporting the moderating role we suggest.

Both the salience of the promise and the level of equity affect the degree to which a consumer's input $\rightarrow$ outcome link is moderated (Figure 3), and thus, the impact of equity on observable outcomes. A high level of equity for a brand with a salient promise should influence outcomes in favour of that brand. A large amount of equity will have little impact on a consumer who believes the strong promise of a brand in a category for which he is not a prospect. For example, a young person may have developed a large amount of equity for Pampers even though she is not yet in the market for diapers. This demonstrates yet another reason why outcome measures do not fully capture brand equity.

This definition and operationalisation are in line with Farquhar's ${ }^{28}$ and Punj and Hillyer's $^{29}$ suggestions that the brand equity construct is conceptually similar to attitude strength, and should manifest the intrapersonal advantages of strong brands proposed by Keller. ${ }^{30}$ Thus defined, brand equity should result in (1) biased processing of information, (2) persistent attitudes or beliefs that are (3) resistant to change, and

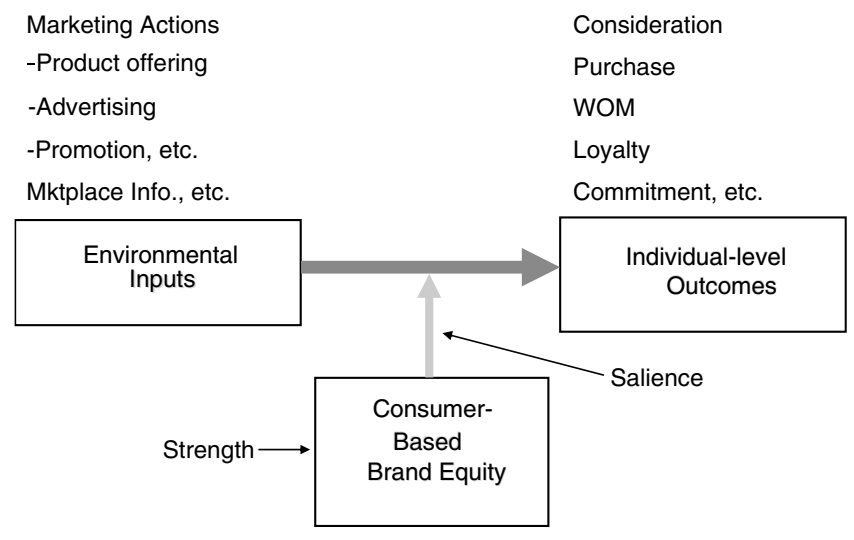

Figure 3 Brand equity as a moderator of marketing activity $\rightarrow$ consumer action link 
(4) behaviours that are influenced by those beliefs. ${ }^{31}$

Since each consumer has his or her own perceptions about the salience of a promise of benefits and the brand's performance, brand equity must be an individual-level construct, implying that neither the brand nor the firm 'owns' a brand's equity. ${ }^{32}$ We suggest that rather than thinking about managing brand equity, brand managers instead should focus on leveraging the equity that resides with individuals in order to maximise brand value, which necessitates a change from being inward-focused (company) to outward-focused (consumers).

Consider a generalised scenario based on Figure 3. The environment, including the marketplace with its marketing messages, provides information and offers options to individuals (input). Individuals draw on their experience and associations in memory (which contribute to consumer-based brand equity) to make a decision and decide upon a course of action. Some individual-level outcomes such as purchase will be visible in the marketplace and added to the aggregate view of the market (firm's perspective; not shown in Figure 3), while others such as adding a product to a future consideration set (eg in a different context) are not picked up in an aggregate outcome measure. Relying only on visible outcome measures (eg purchase) would not capture the true total amount of brand equity that a consumer holds for a brand. Likewise, simply aggregating the outcomes across all consumers will not capture the total amount of equity for the brand in the marketplace.

For example, while shopping for a car, a consumer may strongly consider a 'sporty' brand, but not purchase that brand after concluding that it will not meet the needs of his growing family. As an outcome of that same shopping experience, he may also, however, decide that the 'sporty' brand would be a great rental for the romantic getaway he is planning. Brand equity for the 'sporty' brand may even go up. But if purchase were required for brand equity to exist, one would conclude that there was no brand equity for the 'sporty' brand, yet it is clear from the way the brand impacted his thinking that brand equity may indeed exist. Purchase of the 'family' brand would be noticed in the marketplace-even if the purchase were driven purely by utilitarian considerations rather than the effects of brand equity - yet, the addition of a brand to a future consideration set would not.

What becomes clear is the fact that equating brand equity with marketplace outcomes bypasses all of the changes that can occur in consumer attitudes, perceptions, beliefs, etc yet it is what happens in the (heart and) mind of the consumer that determines brand equity. Moreover, even actual purchases do not reveal whether the observed outcome is due to brand equity. ${ }^{33}$ The decision to purchase could be based on a careful consideration, be simply due to inertia or laziness, or even be a mistake. Furthermore, perceptions can exist at either a detailed attribute or an overall brand level, and brand equity may be based on perceptions that relate to specific attributes for one consumer or those that relate to some overall brand impression for another. ${ }^{34,35}$ Thus, it should be clear that while aggregate marketplace measures may capture part of the brand value for the firm, such measures miss the moderating impact of brands on individuals, which is the domain of brand equity.

It is important to distinguish between brand equity's effect and its existence. Brand equity may exist even in cases where purchase is habitual and based on 
Table I Sample situations in which brand equity may become activated

I. Changes in the consumer's personal or usage situation

2. The introduction of a new brand into a category or assortment

3. Changes (positive or negative) to an existing product

4. Brand extensions

5. Product harm crises

6. Claims made by a competitor

7. Word of mouth

8. Out-of-stock

inertia (or even addiction). In such cases, at some point in time, and as a result of his or her positive experience with the brand, brand equity was developed and had an impact on the consumer, making future purchases habitual. Once a habit is formed, its maintenance may be affected by brand equity only to the extent that the equity causes the person to not reevaluate his or her consideration set, even in the face of new information or choices. For example (consistent with Figure 3), if a loyal Diet Coke consumer hears that a new beverage is available or that aspartame may be linked to memory loss (input), brand equity moderates the impact of that new information, and may affect his or her decision to continue purchasing Diet Coke (outcome). Moreover, in this case, the consumer may decide to stop drinking Diet Coke for health reasons but retain a high level of brand equity. Over time, if not reinforced or, contrariwise, reduced by reports that, say, Coca-Cola suppressed evidence of health risks, this equity may diminish. As demonstrated previously, lack of purchase alone does not, however, prove that brand equity does not exist.

In situations that force consumers to reconstruct their consideration sets and reevaluate the options available, ${ }^{36}$ brand equity may help consumers demonstrate trust in a brand's promise of benefits (see Table 1 for a representative list of scenarios).

Although brand equity is not required to maintain consistent choice, consistent performance by a brand may contribute to its brand equity, which makes it possible for even an 'expert' to hold significant amounts of brand equity for a well-known brand. For example, its regular users may believe that Diet Coke consistently meets its promise of benefits, and this awareness lead to increased levels of brand equity for those consumers.

Finally, brand equity for one brand in a category is not mutually exclusive. This characteristic distinguishes brand equity from brand attachment. As Thomson et al. ${ }^{37}$ indicate, 'a strong emotional attachment is characterised by a perception that the object is irreplaceable'. Equity for multiple brands in a category exists simultaneously within a consumer; thus, choice (purchase) of one brand does not indicate a lack of brand equity for other brands. This logic is especially true of the relationship between the brand equity of private labels and national brands. The purchase of a private label does not indicate a lack of brand equity for a national brand; instead, it simply may suggest that the interaction of marketing activity and equity for the national brand did not produce a sufficient reason to purchase.

\section{Brand value}

Brand value represents what the brand means to a focal company. Brand value may vary depending on the owner (or potential owner) of the brand, because different owners may be able to capture more or less potential value according to their ability to leverage brand equity. More formally, we define brand value as the sale or replacement value of a brand. Brand 


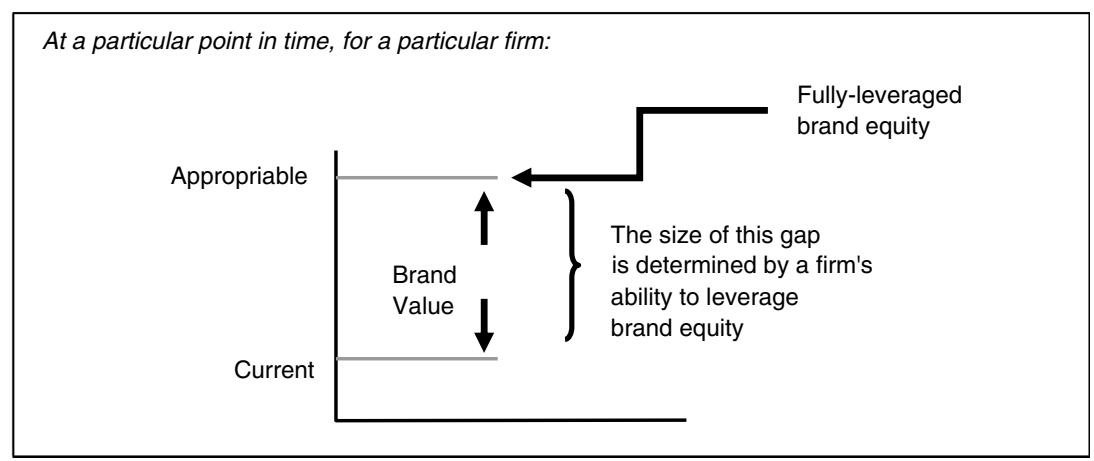

Figure 4 Levels of brand value

value is impacted by brand equity to the extent that brand equity contributes to more positive financial outcomes in favour of the brand (ie those that are visible in the marketplace such as purchase). We have demonstrated that brand equity may exist within consumers and produce positive outcomes such as consideration, or exist within consumers who are not prospects for a particular brand, but these outcomes would not impact current brand value.

In Figure 4, we introduce two important levels of brand value: current and appropriable. Both are subjective and depend on the resources and capabilities of a focal firm. For a particular firm at a particular point in time, all other things being equal, the firm will recognise a brand's current value. A higher appropriable value, ${ }^{38}$ however, might be accessible if the firm were able to perfectly leverage the existing brand equity. Both values represent the net present value of all future brand profits. Thus, current value is based on projected profits that will accrue to the current owners with the existing strategy, capabilities and resources, whereas appropriable value is based on the projected profits that would accrue to a firm that fully leveraged the existing brand equity. In other words, current brand value defines what is for a particular firm, whereas appropriable value defines what can be, if brand equity is fully leveraged.

Estimates of appropriable value can be based on sources that include the superior resources or capabilities of competitors, which allow them to leverage more of the brand's equity, or the 'vision' of an individual or firm. For example, in October 1997, the Cracker Jack brand was owned by Borden and consumers held a certain amount of equity for the Cracker Jack brand. Borden sold Cracker Jack to FritoLay, which owned a 15,000 truck directto-store delivery system that one industry consultant estimated 'would add 10 to 15 market share points in the category'. ${ }^{39}$ Borden may have recognised that Cracker Jack would benefit greatly from FritoLay's core strengths-distribution and marketing - and that Frito-Lay would pay more to purchase the brand than any profits Borden could achieve on its own because of its more limited resources and capabilities. Frito-Lay was able to double Cracker Jack sales and post double-digit sales increases in the two years after purchase. ${ }^{40}$ Thus, the decision by Borden executives to sell Cracker Jack made good business sense because they knew that the Cracker Jack brand would be more valuable within the Frito-Lay system than it 
could be in their own system. That is, Frito-Lay knew that it could leverage more of Cracker Jack's brand equity than could Borden. And Borden was able to capture more of the brand's appropriable value by selling it to Frito-Lay than by owning it and increasing its investment in the brand.

Further distinguishing between brand equity and brand value, we note that brand value is impacted by managerial decisions related to pricing, brand scope, segmentation, positioning, etc. Additionally, brand value accrues to firms from sources not directly related to customers or consumers in general. Patents, trademarks, channel relationships, superior management and creative talent are brand assets that contribute to brand value, but since they are not derived from consumers, they should not be considered a component of brand equity. These assets allow a firm to exclude/reduce competition (eg patents and trademarks), or create and leverage brand equity (eg management and capabilities), thus are valuable to a firm.

Further, Del Vecchio et al. ${ }^{41}$ demonstrate that strong brands enable companies to hire better people cheaper, which lowers human resource (HR) costs. Because employees need not be prospective consumers of the company's products, it follows that any value added through reduced HR costs (or other overhead items) are not directly affected by customers or consumers in general, but they do affect the profitability (and thus the value) of the company's brands. Their research provides evidence that brands contribute value in ways that are not measured by contribution-based methods (eg CLV), which ignore the positive impacts of brands on overhead costs, but should be considered in the sale or replacement value of the brands. Del Vecchio et al. also suggest that brands could contribute value to their firms through relationships with capital markets (eg more attractive credit terms), governmental or regulatory agencies (eg more attractive tax incentives) and the channel (eg easier access to shelf space). Ultimately, the total value that a brand contributes to the various areas of a firm should have an impact on shareholder value.

To summarise, we argue that brands generate value for their owners through two general mechanisms: directly through the sales volume and profitability enabled by firm resources and capabilities and indirectly by lowering costs in areas such as HR. ${ }^{42}$ Therefore, customer equity, a CLV-based approach, captures only a part of overall brand value, since it does not include the overhead cost-reducing benefits of strong brands.

Furthermore, brand value has two features that distinguish it from the CLVbased customer equity construct. First, brand value considers profit from all sources, whether or not they are directly related to customers (ie licensing, patents, tax incentives, attractive loan rates). Secondly, it considers both current and appropriable brand values, which make the brand value construct more comprehensive and applicable to the firm as a whole. ${ }^{43}$

\section{BRAND EQUITY/BRAND VALUE CONCEPTUAL MODEL}

Having presented our views of brand equity and brand value, we now present a conceptual model that positions the two constructs within a larger framework. Models describe the components of brand equity ${ }^{44,45}$ or the impact of brand equity, ${ }^{46}$ but to date, no model provides a comprehensive view of the development of brand equity from different sources, the impact 


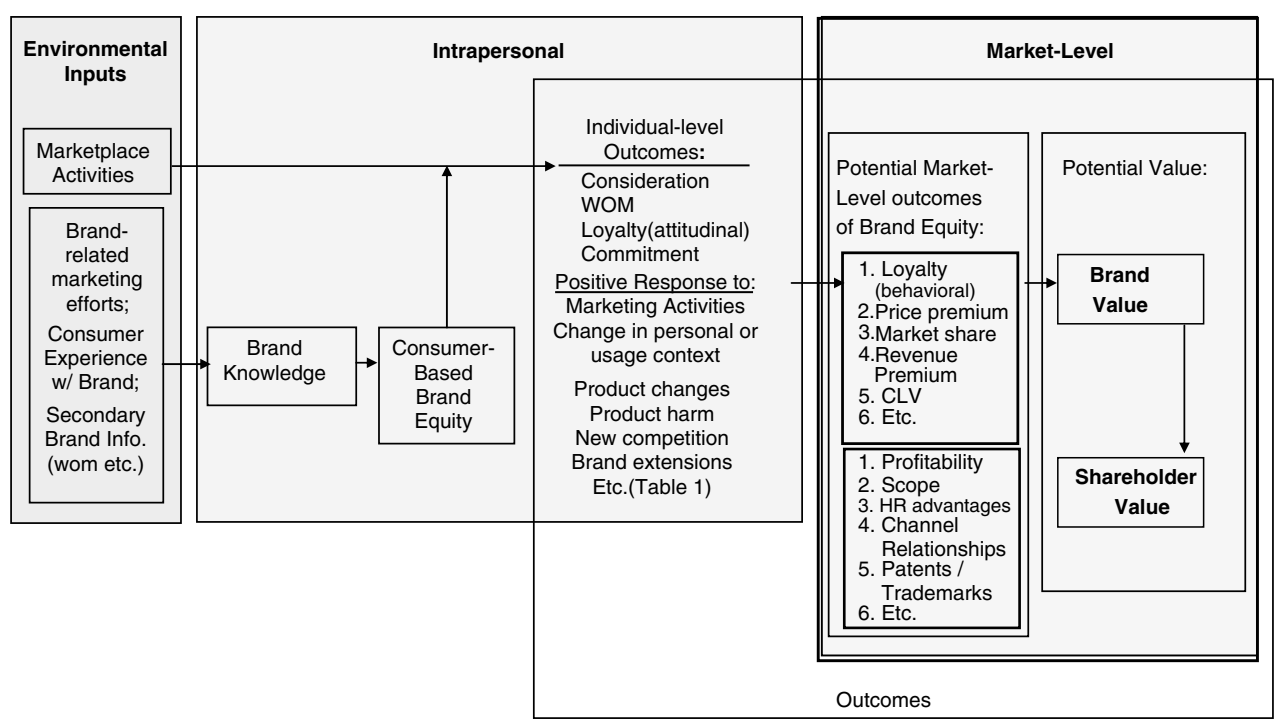

Figure 5 Brand equity/brand value conceptual framework

that brand equity has on individuals, and how this individual-level impact appears in marketplace metrics. Our model demonstrates that traditional measures are at least two stages removed from the consumer, which may explain the potential disconnect between actual brand equity and outcomes that can be measured in the marketplace.

Our model is not intended to describe the components or dimensions of brand equity or how it impacts choice; however, it can be modified to bring in other existing consumer behaviour theory ${ }^{47}$ that influences judgment and decision making.

In Figure 5, we present our generalised brand equity/brand value conceptual model, which integrates existing brand equity components and demonstrates the separation of brand equity and brand value established earlier. This model is a more complete extension of the example provided in Figure 3. Recall that we defined brand as a promise of benefits to the consumer. Differentiation in perceived ability to meet that promise contributes to brand equity. Brand equity is the perception or desire that a brand will meet a promise of benefits. Brand equity is an intra-individual construct similar to attitude strength. ${ }^{48}$ The literature on attitude strength $^{49}$ suggests that brand equity should result in (1) biased processing of information, (2) persistent attitudes or beliefs that are (3) resistant to change and (4) behaviours that are influenced by those beliefs. Behaviours consistent with high levels of salient brand equity are more positive responses to product changes (improvements/mistakes), product harm, ${ }^{50}$ new competition, brand extensions ${ }^{51}$ and so forth (Table 1), plus consideration, purchase, word of mouth, commitment, attachment, etc. Aggregation of individuallevel behaviours that are visible in the marketplace lead to the traditionally measured firm-level outcomes (eg loyalty, price premium, market share). Note that CLV, and therefore customer equity, is considered a market-level outcome. This is consistent with Rust et al.'s2 conceptualisation of customer equity, which considers value equity, retention equity, 
and brand equity as drivers of customer equity.

The model recognises that we must distinguish between what happens external to and within the individual: The environment, including the marketplace and its offerings, messages, etc are 'inputs' to the consumer. Intrapersonal constructs operate within an individual and are not outwardly visible (though they may impact visible behaviour). Market-level constructs are visible and measurable from a firm's perspective. The model also clearly distinguishes outcomes (eg purchase) from inputs (eg advertising) and drivers or moderators of those outcomes (eg brand equity).

From Figure 5 we see that environmental inputs (eg choice situation) reach a person and are impacted (moderated) by existing consumer-based brand equity. This consumer-based brand equity has been built by experience, associations, advertising, word of mouth, etc which are summarised in the model as brand knowledge. A positive amount of salient brand equity may produce a more positive response in favour of a target (or incumbent) brand, which would be considered an individual-level outcome. Individuallevel outcomes may or may not be observable, as demonstrated above. Note that observable individual-level outcomes (behaviour) may even be contrary to the impact of brand equity. For example, when faced with a product harm crisis (eg the Tylenol tampering case), consumers may choose to avoid the brand in question for a while but give it the opportunity to correct the problem in the future ${ }^{53}$ because of positive equity for the brand. Other consumers, however, may respond to a crisis by choosing to switch to another brand for the long term.

Individual-level outcomes that involve observable behaviours may be aggregated at the market level and classified as poten- tial outcomes of brand equity, which then can be considered the consumer-based component in the calculation of brand value. In turn, the accumulation of the value of all brands in a firm's portfolio contributes to shareholder value.

This model is not a choice model but instead is intended to demonstrate the relationship between brand equity that exists within consumers and observed or unobserved individual- and market-level outcomes, and then to show how these outcomes impact brand (and ultimately shareholder) value. On the basis of our demonstration that purchase is not a reliable measure of brand equity, we choose not to include it in the model except at the aggregate market level. The model shows how aggregate market-level outcomes are produced and suggests several places at which there is not a consistent one-to-one mapping between brand equity and outcomes, that is where 'slippage' may occur between brand equity and outcome measures.

An important feature of this model is its distinction between environmental and intrapersonal components. Keller ${ }^{54-56}$ suggests that environmental elements contribute to eight dimensions of brand knowledge and that brand knowledge leads to brand equity. We supplement Keller's view by addressing what happens as a result of any changes in brand equity and whether the outcomes are intrapersonal or market-level, observable or unobservable. Furthermore, we add insight into how equity contributes to value.

The model also is consistent with inertia, as well as with context effects such as blocking, ${ }^{57}$ mere measurement, ${ }^{58}$ compromise, $^{59}$ attraction $^{60}$ and trivial attributes, ${ }^{61}$ that have been proposed as brand equity effects. Such effects may not change equity levels, but may impact the salience of a brand's promise and therefore 
the impact of equity on the marketing activity $\rightarrow$ consumer behaviour path. Also, an accumulation of experience driven by context effects, peripheral processing or inertia may inform more thorough processing in the future, resulting in the development of equity for the brand and, ultimately, a positive impact on value.

\section{CONCLUSION AND FUTURE RESEARCH OPPORTUNITIES}

We have presented a new conceptual model that establishes brand equity and brand value as two related but separate constructs. Brand equity, which implies a consumer-based focus and affects consumer decision processes in a manner similar to that of attitude strength, represents one of many factors that contribute to brand value, which we define as the sale or replacement value of a brand, and which implies a company-based perspective. Because brand equity and brand value imply unique perspectives, and because brand value is a broader construct that subsumes brand equity along with other constructs, the two cannot be 'different sides of the same coin'. We believe that theoretically separating the constructs is a first step toward the development of better measures of each. Thus, the main contributions of this paper are (1) the spotlight it focuses on the newly created space between the constructs, and (2) the idea of leveraging brand equity to create brand value.

From a managerial standpoint, brand managers' primary task is to maximise and leverage brand equity to increase brand value. The proposed framework provides these brand managers with a more comprehensive understanding of the component parts than has been presented in the literature. The framework also applies the concept of appropriable value to the brand equity literature, which is consistent with both literature on mergers and acquisitions ${ }^{62}$ and current managerial practice (eg P\&G's value pricing ${ }^{63}$ ). An interesting question for further research is whether well-known brands have higher market capitalisation than do less wellknown brands due to higher estimates of appropriable value. Our framework suggests that this would be the case when the more well-known brands enjoy higher brand equity among consumers than do the less well-known brands.

We offer four additional considerations. Future operationalisations of brand equity should:

1. consider noncustomers and future potential;

2. consider differences across markets or usage occasions;

3. not assume that all firms share the same goals and objectives and

4. not emphasise short-term effects that may be 'vulnerable'.

From a managerial perspective, the failure to address these issues may result in measures that do not track consistently with changes in the underlying consumer brand equity.

Future potential in terms of future revenue stream and brand extendibility is influenced by the perceptions of current customers and noncustomers, but outcome measures may not account for future profitability or potential. ${ }^{64,65}$ The framework suggests that any complete measure of brand equity should consider noncustomers, though noncustomers are valuable only to the extent that they either will become customers in the future or will positively influence others. ${ }^{66}$ Thus, appropriate measures should account for heterogeneity in the value that accrues from current noncustomers. For example, if one 
of its attributes keeps certain consumers from buying an offering as it is currently configured, then removing or changing that attribute may increase the likelihood that those consumers will purchase that (or another) offering in the future. In this case, brand equity does not have to increase as a result of the product change for the consumer to start buying the brand; instead, the change simply may have allowed the consumer to act on preexisting brand equity.

As we stated in the introduction and evidenced by the prominence that brand equity research has attained within the marketing discipline among both researchers and practitioners, the great task remaining is the development of accurate and managerially useful measures of brand equity. Our discussion and framework suggest that in the marketplace, brand equity impacts consumer information processing, judgment and choice, but is separate from the outcomes it may influence. We proposed that brand equity is a moderator of marketing activity, but this proposition should be supported by empirical evidence.

We have discussed several situations in which brand equity is likely to reveal itself (Table 1). Therefore, brand equity might be measured by asking consumers specifically about how they would react to each of the identified situations as they pertain to a particular brand. Responses could be compared across brands that compete in the same category to provide relative measures. It is not clear whether absolute measures of brand equity are useful; therefore, it may not be appropriate to compare brand equity measures for brands across categories. This question thus is left to further research.

Moreover, our framework suggests that a minimum threshold level may be required before brand equity influences consumer behaviour. The existence of thresholds has not been suggested in previous literature. Therefore, empirical research should investigate this issue to determine the extent to which thresholds exist and how they affect marketplace outcomes. Combining the concepts of thresholds and current noncustomers, we suggest that the most important noncustomers are prospects whose brand equity level falls just below their threshold. Thus, a distributional perspective on brand equity, as opposed to an aggregationist view, should provide a clearer understanding.

\section{References and Notes}

(1) Keller, K. L. and Lehmann, D. R. (2002) 'The Brand Value Chain: Optimizing Strategic and Financial Brand Performance', Dartmouth College, Hanover, NH, Working Paper (see p. 1).

(2) Krishnan, H. S. (1996) 'Characteristics of memory associations: A consumer-based brand equity perspective,', International Journal of Research in Marketing, Vol.13(October), pp. 389-405 (see p. 390).

(3) Rust, R. T., Zeithaml, V. A. and Lemon, K. N. (2004) 'Customer-centered brand management', Harvard Business Review, Vol. 82(September), pp. 110-118 (see p. 118).

(4) Simon, C. J. and Sullivan, M. W. (1993) 'The measurement and determinants of brand equity: A financial approach', Marketing Science, Vol. 12 (Winter), pp. 28-52 (see p. 29).

(5) Srivastava, R. K. and Shocker, A. D. (1991) 'Brand equity: A perspective on its meaning and measurement', MSI Working Paper Series, Report No. 91-124.

(6) C.f., Keller and Lehmann, ref. 1 above.

(7) Rust, R. T., Lemon, K. N. and Zeithaml, V. A. (2004) 'Return on marketing: Using customer equity to focus marketing strategy', Journal of Marketing,Vol. 68(January), pp. 109-127.

(8) Ailawadi, K. L., Lehmann, D. R. and Neslin, S. A. (2003) 'Revenue premium as an outcome measure of brand equity', Journal of Marketing, Vol. 67 (October), pp. 1-17.

(9) Keller, K. L. (1993) 'Conceptualizing, measuring, and managing customer-based brand equity', Journal of Marketing, Vol. 57(January), pp. 1-22.

(10) Ibid., p. 597.

(11) Barwise, P., Higson, C., Likierman, A. and Marsh, P. (1990) 'Brands as separable assets', Business Strategy Review, Vol. 1(Summer), pp. 43-59.

(12) Keller, ref. 5 above. 
(13) Feder, B. J. (1997) 'Quaker bites the bullet, sells Snapple to Triarc', The New York Times, March 28.

(14) Because we conceptualise brand value as firm specific, it is not the same as 'value in use' or a 'value proposition', both of which are consumerbased concepts and therefore not consistent with the company perspective of brand value. The best consumer-based financial brand valuation measure assesses the consumer's willingness to pay (eg Wertenbroch, K. and Skiera, B. (2002) 'Measuring consumers' willingness to pay at the point of purchase', Journal of Marketing Research, Vol. 39(May), pp. 228-241).

(15) Keller, ref. 5 above.

(16) Rust, Lemon, and Zeithaml, ref. 3 above.

(17) Rust, Zeithaml, and Lemon, ref. 1 above.

(18) Rust, Lemon, and Zeithaml, ref. 3 above.

(19) Rust, Zeithaml, and Lemon, ref. 1 above.

(20) Clifton, R. and Simmons, J., (eds.) (2004) 'Brands and Branding', Bloomberg Press, Princeton, NJ.

(21) Ward, S., Light, L. and Goldstine, J. (1999) 'What high-tech managers need to know about brands', Harvard Business Review, Vol. 77(July-August), pp. 85-95.

(22) Webber, A. M. (2000) 'Trust in the future', Fast Company,Vol. 38(September), pp. 210.

(23) Kotler, P. (1977) 'Marketing Management: Analysis, Planning, Implementation, and Control 3rd edn, Prentice Hall, Upper Saddle River, NJ.

(24) Penrose, E.T. (1958) 'The Theory of the Growth of the Firm', Wiley, New York.

(25) Rossiter, J. R. and Percy, L. (2001) 'Emotions and motivations in advertising', Advances in Consumer Research,Vol. 18, No. 1, pp. 100-110 (see p. 103).

(26) Smith, D. C. and Whan Park, C. (1992) 'The effects of brand extensions on market share and advertising efficiency', Journal of Marketing Research,Vol. 29(August), pp. 296-313.

(27) Srivastava and Shocker, ref. 2 above.

(28) Farquhar, P. (1989) 'Managing brand equity', Marketing Research,Vol. 1(September), pp. 1-11.

(29) Punj, G. N. and Hillyer, C. L. (2004) 'A cognitive model of customer-based brand equity for frequently purchased products: Conceptual framework and empirical results', Journal of Consumer Psychology, Vol. 14, No. 1/2, pp. 124-131.

(30) Keller K.L. (2003) Strategic Brand Management: Building, Measuring, and Managing Brand Equity, 2nd edn, Prentice Hall, Upper Saddle River, NJ.

(31) Petty, R. E. and Krosnick, J. A., (eds.) (1995) 'Attitude Strength: Antecedents and Consequences', Lawrence Erlbaum Associates, Hillsdale, NJ.

(32) Clifton and Simmons, ref. 13 above.

(33) C.f.,Fennell, G. and Allenby, G. (2003) 'An unflattering but fair portrait', Marketing Research, Vol. 15, No. 2 (Summer), pp. 44.

(34) Dillon, W. R., Madden, T. J., Kirmani, A. and Mukherjee, S. (2001) 'Understanding what's in a brand rating: A model for assessing brand and attribute effects and their relationship to brand equity', Journal of Marketing Research, Vol. 38(November), pp. 415-429.

(35) Raggio, R. D. and Leone, R. P. (2005) 'Identifying the sources of brand ratings: A procedure for brand ratings decomposition and selected findings Ohio State University Working Paper. http://www.bus.lsu.edu/raggio/RaggioLeoneBEmeasure.pdf.

(36) For example, Wood, S. L. and Lynch Jr, J. G. (2002) 'Prior knowledge and complacency in new product learning', Journal of Consumer Research, Vol. 29(December), pp. 416-426.

(37) Thomson, M., MacInnis, D. J. and Park, W. C. (2005) 'The ties that bind: Measuring the strength of consumers' emotional attachments to brands', Journal of Consumer Psychology, Vol. 15, No. 1, pp. 77-91 (see p. 79).

(38) For example, Mizik, N. and Jacobson, R. (2003) 'Trading off between value creation and value appropriation: The financial implications of shifts in strategic emphasis', Journal of Marketing, Vol. 67(January), pp. 63-76.

(39) Thompson, S. (1997) 'Frito DSD could revive Cracker Jack', Brandweek, Vol. 38, No. 38, pp. 16 (see p. 16).

(40) Hartnett, M. (2000) 'Cracker Jack', Advertising Age, Vol. 71, No. 27, pp. 22.

(41) DelVecchio, D., Jarvis, C. B. and Klink, R. R. (2003) 'Brand equity in resource market exchanges: Leveraging the value of brands beyond product markets', University of Kentucky Working Paper.

(42) Ibid

(43) We, however, recognise that because brand managers may be able to control only the direct variable costs of their brands, the customer equity construct (which considers only contribution) may be more actionable at operational levels of the organisation.

(44) For example, Keller, ref. 5 above.

(45) Punj and Hillyer, ref. 20 above.

(46) For example, Keller, ref. 21 above.

(47) Petty, R.E. and Cacioppo, J.T. (1986) 'The elaboration likelihood model of persuasion in Leonard, B. (ed.) Advances in Experimental Social Psychology, Vol. 19, Academic Press, New York, pp. 123-205.

(48) Farquhar, ref. 19 above.

(49) For example, Petty and Krosnik, ref. 22 above.

(50) Dawar, N. and Pillutla, M. M. (2000) 'Impact of product-harm crises on Brand equity: The moderating role of consumer expectations,', Journal of Marketing Research, Vol. 37(May), pp. 215-226.

(51) Keller, ref. 21 above.

(52) Rust, R. T., Zeithaml, V. A. and Lemon, K. N. (2000) 'Driving Customer Equity: How 
Customer Lifetime Value is Reshaping Corporate Strategy', The Free Press, New York.

(53) Dawar and Pillutla, ref. 39 above.

(54) Keller, ref. 5 above.

(55) Keller, ref. 21 above.

(56) Keller K.L. (2003) 'Brand synthesis:The multidimensionality of brand knowledge', Journal of Consumer Research, Vol. 29(March), pp. 595-600.

(57) Van Ossalaer, M. J. S. and Alba, J. W. (2000) 'Consumer learning and brand equity', Journal of Consumer Research,Vol. 27(June), pp. 1-16.

(58) Dholakia, U. M. and Morwitz, V. G. (2002) 'The scope and persistence of mere-measurement effects: Evidence from a field study of customer satisfaction measurement', Journal of Consumer Research,Vol. 29(September), pp. 159-167.

(59) Kahneman, D. and Tversky, A. (1984) 'Choices, values and frames', American Psychologist, Vol. 39, No. 4, pp. 341-350.

(60) Huber, J., Payne, J.W. and Puto, C. (1982) ‘Adding asymmetrically dominated alternatives:Violations of regularity and the similarity hypothesis', Journal of Consumer Research, Vol. 9(June), pp. 90-98.

(61) Broniarczyk, S. M. and Gershoff, A. D. (2003) 'The reciprocal effects of brand equity and trivial attributes', Journal of Marketing Research, Vol. 40(May), pp. 161-174.

(62) For example, Barney, J. B. (1986) 'Strategic factor markets: Expectations, luck and business strategy', Management Science, Vol. 42, No. 10, pp. 1231-1241.

(63) Ailawadi, K. L., Lehmann, D. R. and Neslin, S. A. (2001) 'Market response to a major policy change in the marketing mix: Learning from Procter \& Gamble's value pricing strategy', Journal of Marketing, Vol. 65(January), pp. 44-61.

(64) Barwise, Higson, Likierman, and Marsh, ref. 7 above.

(65) Simon and Sullivan, ref. 1 above.

(66) Hogan, J. E., Lemon, K. N. and Libai, B. (2003) 'What is the true value of a lost customer?' Journal of Service Research,Vol. 5(February), pp. 196-208. 